\title{
From laboratory life to newsroom practice: The use of actor-network theory and community of practice to explain newsroom practice and culture: Kurdish Network News as case study
}

\author{
Kovan Hussein Saado \\ Department of Media , College of Humanities , University of Sulaimani, Sulaimani, Kurdistan \\ Region, Iraq. \\ E-mail: kovan.saado@univsul.edu.iq
}

\begin{abstract}
Abdulsamad Qadir Hussein
Public Relations and Marketing Department, Technical College of Administration, Sulaimani Polytechnic University, Sulaimani, Kurdistan Region, Iraq.

E-mail: abdulsamad.qadir@spu.edu.iq
\end{abstract}

\begin{abstract}
:
This paper focuses on the impacts of technological changes in the newsroom practices, taking both Actor-Network Theory (henceforth ANT) developed by Latour, 1992; Callon, 1992 and Law, 1992), as well as the Community of Practice (henceforth COP) developed by Wenger, 1998 and Lave, 1991) in newsroom practices and news-making processes inside the newsroom of $(\mathrm{KNN})$ a Kurdish news channel. The paper argues that both models provide a strong basis of understanding the situation of news practice and constructing a better environment of learning, shared projects, problem solving, focal actor roles, and translation processes.

The paper explores how the ANT and COP models work together to provide in-depth understanding for media researchers in their study of newsroom technology. Through this paper the researcher will provide in-depth understanding surrounding the key concepts and principles of each model and employ these to analyses news practice and contemporary newsroom culture. Through the use of ANT and COP this paper seeks to understand the role of new technology tools, human and non-human actors in shaping journalists' behavior in the newsroom.

The date collection process based on the secondary data includes the in-depth interviews with news making crews in the newsroom and non-participate observation of the situation of automation system newsroom applied by KNN.
\end{abstract}

Key words: Newsroom, Actor-network theory, KNN, Automation system. 


\section{Introduction:}

The key aspect of this paper is to focus on newsroom practice based on the system of automation, in particular the recent changes which delivered new technology to the workplace. Regarding these technological changes, Tozer (2004) argued that the "newsroom system has undergone considerable changes in the last decade. The alliance of new technology, more defined workflow and new exciting technology will continue and enhance the immediacy of news" (Tozer, 2004, p.668). Such significance of these technological changes in the newsroom practices initiates with the introduction of the desktop workstation computer, which includes the Central Processing Unit (CPU) (Keirstead, 2004). This paper explores how journalists and news practitioners in newsroom conduct and interact with digital equipment in news-making process. Hence, Pavlik (2001) argues that the "converging computing and telecommunications technologies are rapidly rewriting the traditional assumptions of newsroom organization" (Pavlik, 2001, p.108). Thus, the implementation of the automation system in the newsroom provides the journalists opportunities to conduct their practice in more efficient ways. Within these rapid developments of technological tools determines the roles, relationships, learning processes and connections between the human and nonhuman actors in the process of news-making.

Here, only a handful of the relevant literature including ANT and COP touches the communication and media some of them are merely relevant articles, which mix the actor-network theory and community of practice in the field of media. Weiss and Domingo (2010) examined COP and ANT as theoretical methods to investigate innovation in online media newsrooms. The key purpose of their paper was to construct a theoretical framework to analyse the circumstances of journalism, and to establish how these new technology tools are integrated into the social structure and journalists' practice in the newsroom network. This paper specifically focuses on news production, everyday practice and the use of new technological equipment such as automation systems. Weiss and Domingo (2010) suggest that these methods are great tools to understand and provide description of the actors that are involved in the processes of innovation and decision-making in the newsroom. In the same combined approach, Esnault et al. (2006) [the ANT and COP models] of practice and in the participatory design to provide analysis around the design the European project called ' PALETTE'. Esnault et al. (2006) argued that the combination of these models provides a significant explanation related to the development of interoperable services, particularly also COP and ANT offer a more effective means of analysing a project when combined within Participatory Design methodology.

In this context, Fox (2000) argues that ANT and COP provide an in-depth understanding related to organizational learning. These two approaches feed each other to contribute and obtain understanding, specifically related to the learning process. The key discussion point of Fox (2000) draws "attention to the concept of power embedded in actor-network theory, which he sees as having more in common with that of Foucault than Lave and Wenger" 
(Hughes, Jewson, \& Unwin, 2013, p.8). Also, Fox (2000) argued that both COP and ANT approaches can be more beneficial and offer a better understanding of the circumstances of organizational learning.

The COP proposed by Wenger (1998) is an essential tool to describe the community of journalists in the newsroom, and it especially provides an explanation of the key aspects of the community including news practice, journalists' identity, the learning process, relationships, shared projects, knowledge and exchange of experience between the members of the newsroom network. In this context, the COP model is a vital way to obtain an understanding related to the learning process and how information is transferred between members in the modern newsroom, especially in the community of journalists that is based on the automated system. Furthermore, the concept of Community of Practice, Wenger (1998) is mainly based on how the individual members in the community attempt to learn by participating and joining in shared projects with other members (Fox, 2000). In this context, the journalists as key members of the newsroom network attempt to learn more during their everyday practice and interactions with other practitioners.

Additionally, ANT theory has been used and accepted in the field of media as reviewed above, as well as being used as a fundamental tool to describe the heterogeneous network of human and non-human actors. In this context, actor-network theory is an appropriate approach to adopt in the newsroom network and identify key elements involved in the news production network. In the view of using COP and ANT, Barton and Tusting (2005) provide essential metaphors as an explanation related to the uses of these two approaches, referring to the concepts of "network" and "nodes" rather than Wenger's notion of "community" (Barton\& Tusting, 2005, p.28). Through these two perspectives this paper will attempt to interpret the situation of news network production in the contemporary newsroom.

The newsroom automated system provides more stabilization for the network, in particularly for the management of the translation process, thus the technological system of the newsroom combines the process of news production and news operation that comprises human and non-human actors. This aspect supports the human actors to conduct their practice in a more flexible way and leads to the integration of news production in the newsroom network and makes more powerful actions, for instance journalists have greater ability in the automation system to apply the rule of writing to pictures and also, involves editing footage in the same deskwork. Moreover, the new technology offers the newsroom community a system for organising collaboration of the news practice, and the processing skills of journalists to conduct everyday tasks and also, the ability to control the news production. In the context of the automated newsroom system, the journalists deal with multi-skills and multi-media, which makes the news practice more dynamic. 


\section{Newsroom automation and journalists' practice:}

The newsroom is an essential workplace for journalists' practice in the television station. Recent changes in the field of media in the twentieth century have significantly, impacted on newsroom practice and journalists' performance environment. This aspect has led to journalists fully adopting digitization and computerization tools in their everyday practice (Quinn, 2002). In this context, the journalists' actions are made more effective in the newsroom network, particularly in dealing with news flow information, connecting with other news members and providing direct feedback on news items to the news producer. In this way, there is a range of newsroom software that has a significant function in the process of news production and news management operations. Here are some of the popular software applications used in the television newsroom: AP ENPS, NEWSKING, EZ NEWS, Avid iNEWS, BURLI, etc (Silcock, et. al, 2009).

These automation systems in the newsroom provide journalists with effective tools and a range of facilities in their everyday life in the workplace network. A recent paper by Silcock, et al. (2009) also supports the notion that the automation system in the newsroom has had a significant impact on news workers' practice, especially since this software in the workplace automatically adjusts the timing of the individual journalists in conducting their news stories, for instance, the anchor reader, news presenter or a reporter's news package (Silcock, et al., 2009). Professor Ken Fischer, who taught broadcast journalism at many universities in the USA, identified several key functions and jobs of the automation system in the newsroom, including script-writing tools, showing rundown lists, prompting capability, an archiving system, flexible wire access, sharing tasks, desks and functions with other journalists, automatic researching and a flexible way of dealing with CG (Silcock, et al., 2009). This aspect of the automation system in the newsroom provides more opportunities for journalists to construct their relationships with other news members, connect with management, mutual engagement in the news production process, provide feedback to each other and engage in the learning process. Also, the journalists interact with other members and create the news package, in particular when dealing with visual, audio and writing elements. This aspect of the newsroom community is an essential part of the concept of a community of practice Wenger (1998). Furthermore, this aspect is also a fundamental feature of scientists' community in laboratory life (Latour and Woolgar, 1979), which will be explained more in the next section.

Regarding the changes of technology and professional practice of journalists in the newsroom, Heinrich (2011) argued that digital tools have essentially changed the methods of information gathering, news production and the way of sharing between newsroom members and broadcasting for the audience. Hence, the journalists face great changes and challenges in their everyday life regarding tasks and news practice in the workplace, especially as they have to deal with new production equipment, work more quickly, interact anywhere, be flexible in their connections and also create a large amount of news production. In this context, Siapera and Veglis (2012) argue that technology tools have allowed journalists a high degree of automation in the operation of news production, connection with 
others and thus improve information sharing within the newsroom network and organization. Furthermore, Siapera and Veglis (2012) demonstrated that the key notion behind newsroom practice convergence is "write once and publish everywhere" (Siapera and Veglis, 2012, p.468). In the case of newsroom networks, this means when writing and editing footage, journalists are able to review items everywhere within the system and also, provide feedback to their colleagues and comments on the stories in an effective way. Through the newsroom automation system, the journalists have the ability to manage and comment on other news items with more interaction. This aspect makes the news tasks more like sharing work between the newsroom members, particularly as the system allows journalists to edit, add information and send feedback to their colleagues in the network.

The new newsroom automation system demands more professional skills and abilities to conduct news practice within the news production network, specifically the journalists need the ability to conduct filming and editing, which require relevant skills to build the news material in an effective way (Hemmingway, 2007). In this regard, Clarke and Bromley (2012) claimed that the "implementation of digital newsroom technology leads to an increasing emphasis on multi-skills, which has become the requirement of broadcast journalists in the digital age" (Clarke and Bromley, 2012, p.92). This means that journalists should have in-depth understanding and views to use the new technology in their everyday working practice. Therefore, news practitioners are able to conduct news practice by their own experience, high level of skills and thus obtain their identity as news workers in the framework of the newsroom network. Furthermore, the changes caused by the new technology have impacted on news desk tasks as this aspect of the news practice requires more skills from news practitioners, particularly the news producer and news editors (Vince and Earnshaw, 2012). Through this aspect of the newsroom, journalists are able to achieve their goals, specifically the news producer (as an example of focal actor in the network) determines the key goals of the news action and activity. In this context, Lugmayr and Dal Zotto (2015) argue that news technology innovation is used to achieve specific goals in particular settings, such as journalists' goals in the newsroom network (Lugmayr and Dal Zotto, 2015, p.102). Hence, the automation system of newsroom provides journalists with significant tools and more ways to achieve the key newsroom goals. 


\section{Laboratory and Actor-network theory :}

This section will introduce the laboratory life of Latour and Woolgar (1979) and provide an explanation of scientists' practice in their workplace network. The key elements of the laboratory story are focused on the scientists' activity and everyday practice in the workplace network. The main aspect of the study by Latour and Woolgar (1979) concentrated on the laboratory as a workplace and network, following scientists in their everyday tasks and practice within their laboratory network. Moreover, Latour and Woolgar (1979) conducted this activity as outsider observers and they attempted to follow the scientists in order to provide an explanation of laboratory workers' everyday life in the processes of scientific tasks and practice. This paper project is based on a detailed investigation related to the scientific practices and the "scientific "culture" to follow in every detail what the scientists do and how and what they think" (Woolgar \& Latour, 1986, p.12). In this context, the authors provide an in-depth explanation of the scientists' tasks as a form of cultural practice in their different domains of action and activity, for instance, the scientists' experiments, their attempts to write papers for conferences, raising funds for their research projects, negotiations between laboratory workers, as well as speaking to audiences (Ritze, 2004, p.434). Hence, the key point of the argument, in the laboratory life project, was to concentrate on the method of everyday activities of the scientists' practice that leads to a construction of the facts in the network and the formulation of a heterogeneous network (Woolgar \& Latour, 1986, p.40). Hemmingway (2007) provides an important demonstration related to actor-network theory that informs the explanation of news practice and is related to the laboratory. In this way, she replaces the word 'scientific' with the word 'news' and also replaces the word laboratory with the newsroom (Hemmingway, 2007). This explanation by Hemmingway (2007) provides us with a justification for using ANT in the field of news production process; in particular there are similarities between the laboratory and newsroom. Furthermore, the newsroom network has many similar characteristics to Latour's and Woolgar (1979) scientific laboratory (Hemmingway, 2007), specifically the construction of news facts, which is similar to the construction of scientific facts, also, the translation process that happens in both networks in order to change the form of things and reach the key goals of the network. In this manner, Couldry (2008) argued that the relationship between ANT and media theory is significant (Couldry, 2008, ).

Fenwick and Edwards (2012) argue that the Actor-network theory is based on the concept "that ideas, practices and 'facts' are effects of heterogeneous webs of relations between actors, or assemblages" (Fenwick, and Edwards, 2012). Hence, the actor-network theory is an essential approach to examine a variety of types of actors and the relationships between them, within the network (Milton and Bandia, 2009). In the case of the laboratory, the ANT provides a vital description related to scientific facts and artefacts, (human and non-human actors) that result from the relationships developing between the scientists' everyday routines within the network, as well as their attempts to form alliances to reach the key goals of the network and accomplish their tasks within the practice (Fenwick and Edwards, 2012). In the field of newsroom practice, journalists and technology factors combined to produce a news 
package, which includes a variety of actors, both human and non-human. In addition, journalists' attempts to organize and construct their package by connecting different types of news elements within the heterogeneous network, including footage, voice and visual aspects. Through this process of translation the actors (both human and non-human) connect together and this leads to the construction of a system order in the newsroom network. Furthermore, the system order helps the journalists to work and conduct their practice to reach the key goals of the news network production determined by the news producer as an example of focal actor in the workplace network. In this way, first of all, the journalists attempt to set up the news practice in the newsroom as a system order to organize the relations between actors and make the network more stable to achieve the key goals of the network. Furthermore, the translation process creates a mixture between various types of actors within the network (Latour, 1993). Similarly, Fenwick and Edwards (2010) argue that the translation process includes a mixture of icons and written texts and then becomes something. Hence, the same translation process happens in the newsroom network, particularly in the making of the news package, this aspect includes mixing between writing text, editing footage, info-graphics and then shaping the news items in the final stage. This aspect of the newsroom network occurs when the human actors conduct their negotiations with other members of the network on one side and follow the key goals of the network on the other side to achieve the goals of the network and thus make the network more stable. moreover, the news producer as an example of the focal actor in the network uses a variety of ways to persuade the actors to follow the key goals. Also, following the instructions of the news producer in the newsroom network and news practice are essential aspects of constructing the system order and making the network more stable.

Callon (1986) identified that the translation process involves four key stages, which are problematization, interessement, enrolment and mobilization. The first step of the translation is problematization, which includes negotiation between actors in order to determine the problem of the network. The second stage is the interessement process, which includes negotiation between actors about their interest within the network. The third stage is the enrolment of the actors, which refers to the actors' acceptance of their role, their position and interest in the context of the network practice. The final stage is mobilization when the focal actor attempts to ensure that the actors accept the key goal and follow the instruction of the network (Tatnall, 2014). In this manner, these steps are reflected in the everyday practice of the newsroom, for instance, during the first step, the journalists in the morning newsroom conference attempt to determine the issues and create the news agenda. During the second step negotiations between journalists aim to create a shared news project, group discussions related to their work and exchange of experience between each other. During the third stage the journalists accept their roles and involvement in the news project and they also follow the key goals of the network. In the last stage, the news producer attempts to check everything in the procedure of news production is going well, and also to ensure that the journalists' news tasks are based on the goals determined in the morning conference in the newsroom network. 
Translation is the key process that makes invisible things visible in the network. Hence, the translation process is more related to the structure of the network and construction of the activity, shaping the behaviour of actors and determining their roles within their framework of the network practice. In this context, Callon (1986) argues that the translation process refers to the continuity of change that happens within the network, in particular it refers to the fact that translation emphasizes the continuity of the displacements and transformations which occur in this story. These displacements of the network goals and interests, along with the displacements of the devices, the human actors and inscriptions occur at all steps of the network (Callon, 1986). In respect to translation in the newsroom network, the process organizes the relationships between actors (both human and non-human), as well as arranges their roles in the network of production, shaping the structure of the network action as well as the association between various types of elements in the network.

\section{Community of practice and newsroom community}

This section provides a wide range of relevant studies to the community of practice (COP) proposed by Wenger (1998). A key aspect of the community of practice is that "a process of social learning occurs when people who have a common interest in a subject or problem collaborate over an extended period to share ideas, find solutions and build innovations" (Ipgrave, et. al., 2009, p.219). In the context of Wenger's definition, the newsroom community and laboratory community cases have the same characteristics of the COP model, particularly since both concepts are based on practice, relationships, learning from each other, common interests, goals between the members of network and also, conducting collaborative work projects in both the workplace and network. This feature is suitable for situations of both workplaces. These two concepts applied to the framework of the newsroom practice.

The key aspects of Wenger's (1998) concepts that contribute to this paper is the learning process, negotiation between members, identity of journalists, mutual engagement, domain of practice, shared projects, resources and sharing the history of learning to achieve the key goals of the network. The learning process is an essential aspect of the community of newsroom and laboratory of the scientists (Latour, Woolgar, 1979). Through the engagement of the journalists in the news project process and interaction with other members, they obtain information, experience and knowledge to conduct their news practice. According to Lave and Wenger (1991), the processes of learning is the essential social aspect of the community (Tsui, et.al., 2008). Comparatively, the key aspect of the journalists' action is the interaction between the news crew, which leads to an exchange of experience and knowledge within the news network production. Through co-working and practice the community network members have the ability to manage their news project, specifically when journalists face problems and ask other members to help them and solve their issues within the workplace. 
A practical example of the learning process in the newsroom network and everyday practice of the members is when the news producer attempts to provide the news practitioners with more details of their news tasks and guides them to achieve the key goals of the news network production. For instance, the news producer often provides instructions to the news editors, news director and news reporters in the morning newsroom conference. This occurs everyday in order to shape the form of the news package that includes footage, visual aspects, graphics and sound bites. It also includes decisions related to the news story contents covering the editorial aspect and information that provides value to the news package. These sorts of tasks happen everyday between the newsroom crew and are managed by in-depth discussion, negotiation, exchange of information and knowledge to construct the news items. In this manner, Didham, et al. (2015) argued "the learning process in COP is dynamic in that renegotiation and change are a continuous part of such practice" (Didham, et al., 2015, p.242). In this way, the key point and notion of the Wenger (1998) model framework is the "community" "practice" "learning" " meaning" "identity" (Wenger, 1998, p.5). Through these elements the ethnographic researcher is able to provide in-depth understanding and explanation of the community of newsroom network.

In the framework of newsroom practice, the community of journalists' practice is an essential aspect of the workplace. In this context, the individual journalists in the newsroom community are engaged in news practice as well as participating in the operation of the news production. Also, in the context of the newsroom setting the key practices are based on news activity and action, in particular, the news process production. Hence, the newsroom setting is shaped by journalists' practice and activity in the workplace. The practice concept is more connected to the learning process in the workplace, as Nicolini, et. al.(2003) claimed, the "COP perspective thus emphasizes knowing in practice as joint enterprise and belonging" to the community (Nicolini, et. al., 2003, p.14). Hence, this means that the journalists' belonging to the community of newsroom is a crucial aspect in conducting their actions, news practice and engagement in the procedure of news network production.

Another essential aspect of Wenger's (1998) concept is the community member. In this way, the journalists are members of the newsroom community, the everyday life, routine and interaction, they share ideas, and language symbols, codes, knowledge, and information and construct a specific social form for their community network. In this way, Schiavone (2013) argued that this aspect of the community is the input of practice, mutual engagement, friendships and involvement in the learning process, which provides the community system with the order and tools to construct the social interaction between the practitioners within their community network (Schiavone, 2013). Hence, the social aspect of the newsroom network is essential to make the network more stable and also, in order to achieve the key goals of the news practice. 


\section{The links between COP and ANT:}

This section illustrates the key arguments related to the links between COP, ANT and newsroom practice, and in particular it provides information about how these concepts fit into the newsroom network practice. In this context, there are common elements shared between these concepts, in particular, a key argument of the COP model is the focus on learning situated socially in the community. Therefore, information and knowledge are embodied in the practice, this aspect is socially reproduced and modified over time within the community network (Jones and Steeples, 2002). This perspective continues to emphasis that knowledge, information and experience are socially shared between the members in the context of the community, rather than individual workers obtaining their opinions without interaction with other members. In this framework, the learning process as an essential aspect of the COP is one of the legitimate areas of peripheral participation. For instance, when new workers join the community network, they learn to conduct their activity, such that it is socially approved by the old workers (Jones and Steeples, 2002). Through interaction, discussion and exchanging their experience with others they are able to learn and conduct their everyday practice within the community. In the context of the ANT approach, this concept particularly deals with the concept that information and knowledge is embodied in the heterogeneous network that includes both the human and non-human actors (Jones and Steeples, 2002). In the same way, Fox (2010), argued that the COP and ANT approach "together make a stronger contribution to our understanding of organization learning" (Fox, 2010, p.853). This aspect of the contribution between these two concepts provides a useful tool to explore and obtain in-depth understanding of the structure of the network.

In terms of the learning process in the newsroom, the journalists directly attempt to become involved in the news activity and action. Through interaction and negotiation related to the shape of their news stories, for instance, the individual journalists face problems in creating their news items, attempting to explain their situation to other colleagues within the network. Through this discussion and exchange of knowledge the journalists learn how to deal with this particular situation and thus obtain the ability to solve their problems in the newsroom network. In this context, there are many activities and actions in the newsroom network that support the process of learning and improve the skills of newcomers by constructing relationships with existing workers. This aspect of the newsroom action and learning provides the journalists with an effective way of finding their identity and role within their community network.

The key questions in this paper address how these concepts provide an explanation of newsroom network practice, as explained above related to the learning process in each framework of the concepts. To return to the laboratory life of Latour and Woolgar (1979), and specifically how this approach closely analysed scientists' practice and everyday life, especially in their work place where they have interactions, share work, exchange information and all this action is based on negotiation between the actors to achieve the key goals of the network. This negotiation 
between the workers provides an effective approach to learn more about their practice and construct how they follow the key goals of the network or even the community leader as an example of focal actor. To do this, the news producer as an example of focal actor in the network, looks closely at the action of the actors and how they follow the network instructions and advice to create their item. Through this aspect the focal actor attempts to ensure that all actors have accepted the goals and programme of action in the network. Hence, by the process of learning, exchanging knowledge and interaction between them, they make the network stable and achieve its key aims.

One of the most common elements among these three concepts is the shared domain (Wenger, 1998), in the newsroom practice, community of practice and laboratory. Through the domain the human actors (journalists, members and human actors) attempt to share their interests, goals and knowledge with other members of the network as a social aspect of their action, for instance, the scientists in the laboratory share their domain to achieve their goals and accomplish their tasks, such as papers, conferences or shared projects with other members of the network (Latour and Woolgar, 1986). moreover

In the filed the newsroom network, the journalists share their domain to conduct the news production process and participate in the procedure of news activity. This aspect allows the news practitioners to engage in the news project, interact with other members to share their experience, and also generate new knowledge to support the news workers to establish a community of interests within the newsroom network (Quinn, 2005).

According to Wenger (1998) the COP model is based on the group workers, teamwork, collaboration tasks and collective learning. Also, the form of the action and activity in the laboratory is based on the collaboration work and tasks between the scientists, for instance, publishing journals, papers or group presentations in conferences (Latour and Woolgar, 1979, p.62). The newsroom practice is established in the everyday routine and collaboration work, for example, teamwork of journalists involved in the coverage of special events in the fieldwork. Hence, through this aspect the human actors obtain the ability to improve their work skills, construct their relationships and make the network stable to achieve the key goals of the action program.

In terms of negotiation and discussion, the three domains confirm that there is a great amount of group or individual negotiation between the members of the network. For instance, newcomers to the community, "negotiated the meaning of her or his everyday practice performance through the interaction with the old workers in order to become full participants in the community of practice" (Bang, 2008, p.25). Also, the new journalists that join the newsroom practice ask old journalists to obtain understanding of the new environment and conduct their practice in an efficient way. Furthermore, in the laboratory network, there is a great amount of negotiation between the actors, specifically the human actors, in order to create and share common interests and goals among themselves. In general terms, this means that negotiation is a fundamental aspect of the three concepts including newsroom practice, COP and ANT approaches.

Additionally, in terms of technological changes in the newsroom, the three concepts are supported by these in many aspects of the community network. For instance, by improving their relationships and connections directly within 
the network, offering a quicker way to interact with members of the network, and providing feedback related to their practice and work. These aspects are delivered with the implementation of the new automation system in the framework of the news production process in the newsroom. Thus, the use of technology tools in the newsroom supports the key common elements of the three concepts in this article.

\section{Case study: KNN and automation system:}

KNN (Kurdish News Network) a television station in Sulaimani city, launched on $31^{\text {st }}$ Dec 2008 belongs to the Wsha Company. Claimed to be the first independent television news station in the Kurdistan region.

In the KNN channel, the newsroom is designed to manage all aspects of process news production process, through new technology and network integration systems connects its news making equipment (Human and non-human actors) with automation news production workflow. This newsroom networking is based on a digital automation system and application software called Avid technology and iNews. In this respect, the automation system in the modern newsroom, for instance, both iNews and Avid technology implementation in the KNN newsroom, allows the journalists and news makers to "monitor incoming news agency, write news stories, work on a rundown list, access the Internet, and access audio or video clips and their network's archives from their desktop"(Meadows, 2007, p.16).

The researchers observed in the newsroom workplace that the workstation from new gathering process, gatekeeping to editing and providing news items procedures on a nonlinear automation system, which provides the journalists, news workers and news producers with new skills to deal with the news production. In addition, the researchers noted that the automation deskwork computer offers the journalists a faster pace of work by using high-level techniques and tools to control the process and to construct news packages.

Another aspects observed by researchers is that automation system in KNN's newsroom offers news productions crew and editors many capabilities to control and manage their production workflow, in particular, generating professional contribution in their news practices, providing comments feedback, emailing each others, reviewing news copies, communicating with the users and peers in the workplace. A senior news reporter through an interview with researchers emphasized on the use of the automation system in their everyday practice, he claimed that:

'...the automation of Avid technology provides our news practices with unlimited facilitates to manage news operations. We don't use tape to record video and audio. We broadcast the news program directly. The system tells us about the duration of news items - 40 to 50 seconds, longest news 40 seconds - but sometimes this duration will depend on the news value and importance of the events'. 


\section{(A News Producer, KNN)}

Through observations both researchers analyzes that, the automation system in KNN newsroom provides great deal facilitating the journalists and news producers to organize their news production workflow and management of news practices within one digital desk duty framework, for instance coordination among journalists allows the news worker to structure the news stories, transform the news to autocue in the news studio and deal with the news program and undertake specific automated search engine.

The researcher perceived that there are different levels of knowledge and experience among the newsroom members, particularly, between the old journalists and new workers in managing their tasks in the workplace. This aspect of the newsroom creates an unstable situation for the news network (ANT) and the focal actor (News producer) attempting to fix, control and solve their problems to bring more stabilization to the workplace network. Another senior news presenter stated that the news presenters has a great amount of knowledge, experience and information related to use of the automation system in KNN's newsroom network. In his comment he stated that:

'... in general the majority of the news anchors are proficient at using the newsroom system. They have skills to use the automation, especially Avid and iNews. They are able to manage their everyday duties. Currently, we have problems in setting up a workshop about the use of the automation system'.

(A News Anchor, KNN)

During his interview the senior news producer in the KNN network claimed that the automation technology, Avid, and iNews system provides them with many benefits in their everyday news practice, making the work easier in the framework of the news production (Senior News Producer, KNN). Also, stated that the use of automation system in the newsroom provides the journalists with new experiences, whilst the news worker has already experienced the non-automation system use. In this respect, he also stated that they found work in the traditional newsroom more difficult compared to having the automation system in the workplace (Senior News Producer, KNN Channel).

The KNN newsroom is therefore a complex network of human and nonhuman actors (ANT) mainly connected through and by the Avid system. The explanations above confirm there is a significant aspect of interaction between heterogonous actors (ANT) within the newsroom automation system. This provides the journalists with more opportunity to conduct their news practice and be involved directly in the workplace learning, exchanging knowledge, sharing news projects and engaging in news activity (COP)(see Wenger, 1998). This makes the news exercise easier than before; particularly, creating linkage with other elements of news production, especially in the rolling 24/7 news operations. 


\section{Conclusion :}

Through observing and analyzing news-making processes in the KNN Newsroom this paper examines how television newsroom practice has been reshaped under technological changes via applying of two key approaches, namely the community of practice (Wenger, 1998) and actor-network theory (Latour, et al.) in order to analyse the news culture, news practice and news production process in the newsroom network.

The key findings of this paper reveal that the new technology has an essential role in organising the relationships between journalists (as human actors) and non-human actors that are involved in the process of news production in the newsroom network. Also, technology is significant in shaping the behaviour of journalists and mapping the newsroom network, especially the use of automated systems. Furthermore, ANT provides a practical tool to explore in-depth information related to the process of translation and how to manage this aspect in the newsroom, in particular, the four key stages of the process. Also, this approach is more beneficial for discovering the position of journalists, their roles in the process of news production and how the newsroom network is shaped. This approach is useful to obtain an understanding related to the process of decision-making by the focal actors as an example of news producers and also, how they inform the journalists to work, follow and apply the focal actor's instructions in the newsroom network to achieve the key newsroom goals. Through this aspect of ANT this paper explores the role of the news producer as an example of focal actor in the process of news production and shaping the news package by their instructions for the news crew.

Also, the use of community of practice in the context of newsroom network offers a useful tool to explain and identify the key aspects of the workplace, including the learning process, negotiation between journalists, identity, mutual engagement, shared domain of practice, projects and shared history of learning in the workplace. The changes in new technology have also impacted on the key features of the newsroom community, specifically shared information, projects and experience. These aspects of change create a new form of interaction between journalists in the newsroom community, in particular, the implementation of the automated system in the newsroom is essential in managing all these operations. The new system is an effective tool to support the process of learning in the newsroom, especially as it has many facilities to encourage journalists to exchange information, feedback and experience related to their news items. Also, the technology system provides the journalists' with effective strategies for being involved in the learning process, and gaining knowledge of their everyday practice. This aspect of the newsroom means that journalists have adopted the new circumstances of practice and are involved in the news production process directly. The COP model addresses the understanding of journalists' skills and the ability of workers in conducting their practice. Also, the technological tools provide vital facilities to the members of the newsroom to create connections with other units to manage the news archive and footage within the network. In 
the context of COP concepts, the shared repertoire, negotiation between members and joint enterprise help journalists to improve their work skills, involving them in the learning process and constructing their relationships with other members is key aspect of the model.

Each human and nonhuman actors (ANT) in KNN newsroom connected through the Avid and iNEWS systems. These interaction systems between heterogonous actors (ANT) within the newsroom automation system offers the journalists with more a better work environments of news producing and exchanging knowledge, sharing news projects and engaging in news activity .

Both COP and ANT are based on the social structure and human actor practice within the newsroom network. In this way, the key focus of the researcher in this paper is on the news practice, news operation and news production within the newsroom network. Finally, this paper concentrates on the newsroom as the central workplace of journalists' activity and action, especially, in conducting negotiations, exchanging information, experience and knowledge that shape the practice and key goals of the network. 


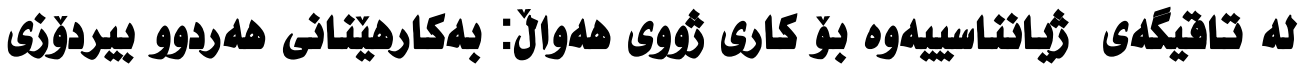

\section{Actor-Network Theory and Community Of Practice}

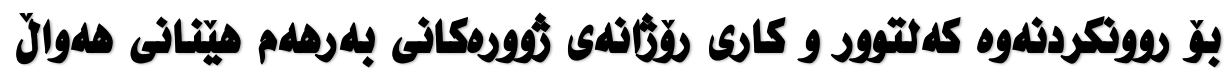

\section{كهنالّ (KNN) به نهووثه}

كوّثان حسيّز سلهعدو

بهشى راكهياندن، كوّليّزى زانسته مروّثايهتييككان، زانكوى سليمانى، سليمانى، هـريّمى كوردستان، عيّراق.

\section{عبلالصمل قتادر حسيّن}

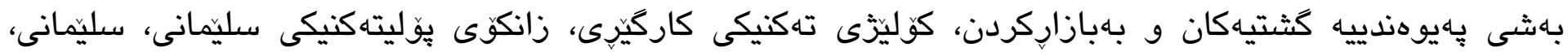
هـاريّمى كوردستان، عيّراق.

ئهم تويزّينهوهيه تيشك دهخاته سهار كاريكهرييهكانى تهكنهلوزيا له كارى ذووردكانى بهرههامينانى هـوال، له ريكّهى

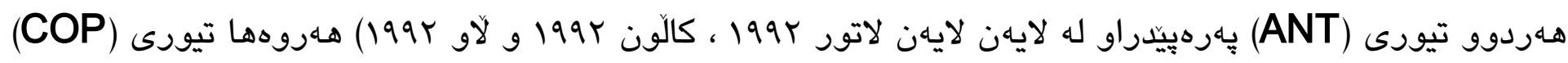

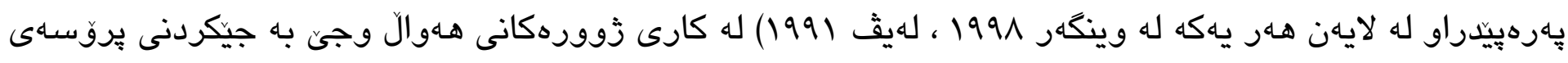

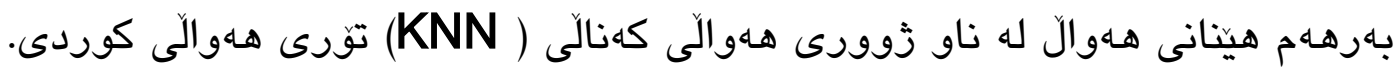

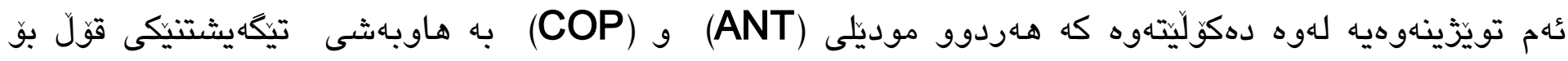

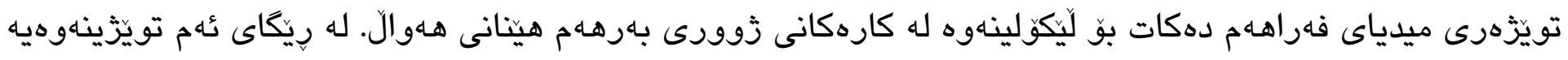

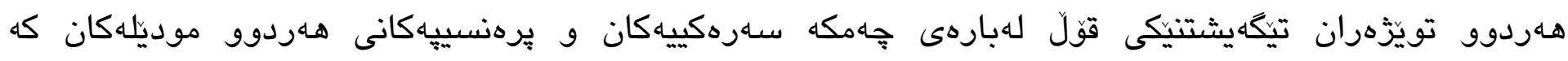
بهكارهاتوون بو شيكردنهوهى كارى بِراكتيكى هـوالَ و كهلتورى هاوجهارخى كاركردنى ذوورهكانى هـوال. ئهم تويَزينهوهيه لهريّى هـرودوو تيورهوه هـول دهدات تيكاهيشتيكى بهرينتر له بارهى كاريكهرى هوكارهكانى 


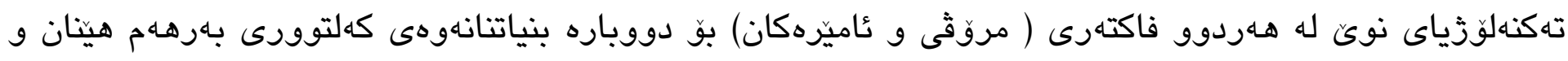

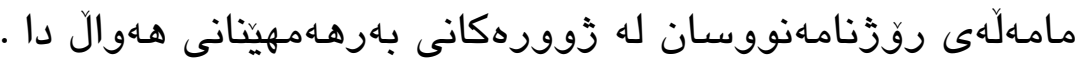
بروّسهى كوكردنهوهى داتا و زانيارييهكان بشت به داتاى لاوهكى و شيّوازهكان جاوديّرى تويَّهران و جاوييكهوتنى قوّل دهبهستيت له كهل تيمى بهرههم هينانى هـوال وجوّنيهتى ئاويتهبوونيان لهكهل سيتهى ، خودكارسازى له نيّو كهنالَى كهى ئين ئين دا.

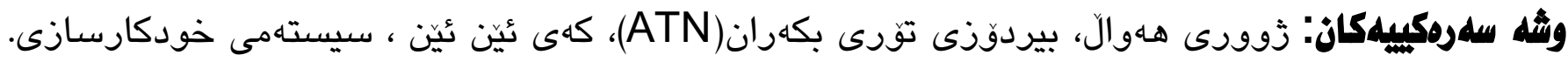




\section{Reference:}

Bang, E. (2008). Inquiry practice and identity of beginning secondary science teachers in the online and offline learning community: A longitudinal mixed methods study. ProQuest.

Barton, D., \& Tusting, K. (2005). Beyond communities of practice: Language power and social context. Cambridge University Press.

Callon, M. (1986). Some elements of a sociology of translation: domestication of the scallops and the fishermen of St Brieuc Bay. The Sociological Review, 32(S1), 196-233.

Clarke, J., \& Bromley, M. (Eds.). (2012). International news in the digital age: East-west perceptions of a new world order (Vol. 4). Routledge.

Couldry, N. (2008). Actor network theory and media: Do they connect and on what terms?.

Didham, R. J., Doyle, D., Klein, J., \& Thoresen, V. W. (2015). Responsible Living: Concepts, Education and Future Perspectives. In Responsible Living (pp. 3-12). Springer International Publishing.

Esnault, L., Zeiliger, R., \& Vermeulin, F. (2006). On the use of actor-network theory for developing web services dedicated to communities of practice. Practice, 298-306.

Esnault, L., Zeiliger, R., \& Vermeulin, F. (2006). On the use of actor-network theory for developing web services dedicated to communities of practice. Practice, 298-306.

Fenwick, T., \& Edwards, R. (2010). Actor-network theory in education. Routledge.

Fenwick, T., \& Edwards, R. (2012). Researching education through actor-network theory. John Wiley \& Sons.

Fox, S. (2000). Communities Of Practice, Foucault And Actor-Network Therory. Journal of management studies, $37(6), 853-868$. 
Fox, S. (2000). Communities Of Practice, Foucault And Actor-Network Therory. Journal of management studies, $37(6), 853-868$.

Heinrich, A. (2011). Network journalism: Journalistic practice in interactive spheres (Vol. 3). Routledge.

Hemmingway, E. (2007). Into the newsroom: Exploring the digital production of regional television news. Routledge.

Hemmingway, E. (2007). Into the newsroom: Exploring the digital production of regional television news. Routledge.

https://www.knnc.net/en/ accessed 1 Sep. 2018,

Ipgrave, J., Jackson, R., \& O’Grady, K. (Eds.). (2009). Religious education research through a community of practice. Action research and the interpretive approach. Waxmann Verlag.

Jones, C., \& Steeples, C. (2002). Perspectives and issues in networked learning. In Networked learning: perspectives and issues (pp. 1-14). Springer London.

Keirstead, P. O. (2004). Computers in broadcast and cable newsrooms: using technology in television news production. Routledge.

Latour, B. (1993). Have we ever been modern. Hemel Hempstead, UK: Harvester Wheatsheaf.

Lugmayr, A., \& Dal Zotto, C. (Eds.). (2015). Media Convergence Handbook-Vol. 1: Journalism, Broadcasting, and Social Media Aspects of Convergence. Springer.

Meadows, M. (2007). The Electronic Reporter: Broadcast Journalism in Australia, 2nd edn [Book Review]. Media International Australia, Incorporating Culture \& Policy, (123), 162.

Milton, J., \& Bandia, P. (Eds.). (2009). Agents of translation (Vol. 81). John Benjamins Publishing.

Nicolini, D., Gherardi, S., \& Yanow, D. (2003). Knowing in organizations: A practice-based approach. ME Sharpe. Pavlik, J. V. (2001). Journalism and new media. Columbia University Press. 
Quinn, S. (2002). Knowledge management in the digital newsroom. Taylor \& Francis.

Quinn, S. (2005). Convergent journalism: The fundamentals of multimedia reporting. Peter Lang.

Ritze, G. (Ed). (2004). encyclopaedia of social theory. Stage Publications.

Schiavone, F. (2013). Communities of practice and vintage innovation: A strategic reaction to technological change. Springer Science \& Business Media.

Siapera, E., \& Veglis, A. (Eds.). (2012). The handbook of global online journalism. John Wiley \& Sons.

Silcock, B. W., Heider, D., \& Rogus, M. T. (2009). Managing television news: A handbook for ethical and effective producing. Routledge.

Tatnall, A. (Ed.). (2014). Technological Advancements and the Impact of Actor-network Theory. IGI Global.

Tozer, E. P. J. (2004). Broadcast engineer's reference book. Taylor \& Francis.

Tsui, A. B., Edwards, G., Lopez-Real, F., Kwan, T., Law, D., Stimpson, P., ... \& Wong, A. (2008). Learning in school-university partnership: Sociocultural perspectives. Routledge.

Vince, J., \& Earnshaw, R. (Eds.). (2012). Digital convergence: the information revolution. Springer Science \& Business Media.

Weiss, A. S., \& Domingo, D. (2010). Innovation processes in online newsrooms as actor-networks and communities of practice. New Media \& Society.

Weiss, A. S., \& Domingo, D. (2010). Innovation processes in online newsrooms as actor-networks and communities of practice. New Media \& Society.

Wenger, E. (1998). Communities of practice: Learning, meaning, and identity. Cambridge university press.

Wenger, E. (1998). Communities ofpractice: Learning, meaning, and identity. New York: Cambridge.

Woolgar, S., \& Latour, B. (1986). Laboratory of Life: The Construction of Scientific Facts. Princenton University. 